\title{
Keynote: New Higher Education for Lifelong Learning
}

\author{
Tom van Weert
}

Hogeschool van Utrecht, Cetis, Centre of expertise for educational innovation and ICT, P. O. Box 85029, 3508 AA Utrecht, The Netherlands

t.vweert@cetis.hvu.nl; http://www.cetis.hvu.nl

Abstract: Economical, societal and cultural developments in industrialized countries push for educational innovation with Information and Communication Technology (ICT) as an important enabling factor. Moving from industrial to knowledge intensive economies there is a need for modern professionals, knowledge workers with new qualifications. For the modern professional, lifelong working is identical with lifelong learning; the modern professional is a learning professional. Innovation is the driving force in a knowledge intensive economy and for innovation new knowledge is needed. The modern professional therefore is a knowledge creating professional. Also businesses and organisations need new strategic business-knowledge to be able cope with demands from a rapidly changing environment. Modern organisations are therefore learning organisations. Higher Education, as a breeding place of modern professionals, needs to redefine its role. The more so, because a new generation of students is in the making: the media generation. A new educational paradigm of the learning organisation may serve both initial phase, and lifelong learning students. Situation based learning environments may be the materialisation of this new paradigm.

Key words: economic perspective, innovation, knowledge creation, learning organisation, learning teams, Lifelong Learning, modern professional, situation based learning, virtual learning organisation 


\section{CHANGES IN OUR ENVIRONMENT}

In rich countries the working and living environment is changing. Take for example The Netherlands, a European country with more than $16,000,000$ inhabitants and a gross national product of 430,000,000,000 Euro. In this small country the economical, social, cultural and political environments are changing.

\section{Economical environment}

\section{Demand for knowledge workers}

In the Netherlands there is a trend towards knowledge intensive production and service providing, called 'knowledge economy'. Take air transport as an example. Amsterdam airport is a major hub which rates high with travellers because of its clever logistics. Schiphol airport's logistical knowledge has become an export product, providing added value. The 'knowledge economy' raises a demand for knowledge workers. The Dutch social-economic advisory board to the government, for example, expects a shortage of 200,000 higher educated workers in 2003 developing into an expected shortage of 400,000 in 2007 (SER 1999).

\section{Working and learning melt together}

To keep up with developments in a knowledge intensive economy (knowledge) workers need to adapt continuously to new developments: they are in a process of Lifelong Learning. "In the old economy, the basic competences of the industrial worker, bricklayer, or bus driver were relatively stable. True, you might have applied these competencies to different situations, such as different construction sites, but the learning component of your labour was small. In the new economy, the learning component of work becomes huge. ........ Think about your own work. Work and learning overlap for a massive component of the workforce." (Tapscott 1996, p. 198)

\section{Knowledge creation at the work place}

Innovation is the driving force in a knowledge intensive economy. To be able to innovate businesses and organisations need business-knowledge, 
supporting decisions to act in their markets. Part of this business-knowledge may be imported from elsewhere, but the strategic part has to be created in house. Knowledge creation is becoming a normal part of the work of knowledge workers. "In the knowledge economy the term knowledge was used originally to denote scientific knowledge. However, partly under the influence of Information and Communication Technology the concept of knowledge is broadening: knowledge, wherever it is stored, becomes available. Knowledge in the heads of or hands of workers can be codified; tacit knowledge can be a commercially valuable asset" (WRR 2002, p. 22; author's translation). Mass distribution of ICT and the Internet seem to contribute towards the development of new knowledge and new attitudes towards knowledge. The concept of knowledge has been extended from purely theoretical knowledge (old knowledge) to knowledge that is also more practice-oriented (new knowledge). (WRR 2002)

\section{Knowledge has an expiration date}

Knowledge can in many cases be compared with fish: before you know it, it is not fresh anymore. And when the time between creation and expiration date is short, traditional knowledge transfer loses value. Fresh knowledge has to be applied Just in Time and traditional knowledge transfer needs time. And knowledge not only has to be fresh, it also has to have a Just Fit. There is just no time to make knowledge fit, when it is loosing its freshness so quickly. Knowledge creation and sharing of knowledge therefore have to be organised in non-traditional ways. In the knowledge economy it is business as usual because loosing time is loosing money. And therefore knowledge creation and knowledge sharing have to be done flexibly in time and place: which flexibility is made possible by Information and Communication Technology?

\section{Social environment}

\section{An 'enterprising' society}

Long term developments lead to fundamental changes in economic activities and put more weight on unique human qualities such as knowledge creation. Robotic type of work is taken over by automates. 'Human capital' is becoming more and more important and allows workers more freedom in giving form to their work commitments. Supported by Information and Communication Technology they become more and more responsible for all 
dimensions of their work. This contributes to the 'wholeness' of working life. "More and more people give meaning to their lives in paid professional work. The reason for this is the changing character of work. By and by an 'enterprising' society of dynamic professionals is developing." (Beek 1998; author's translation)

\section{Children are busy as bees}

Dynamic professionals are a busy lot, always organising and doing things in parallel (being parent, working, relaxing). Wealth and growing importance of the individual lead to 'we want it now', 'we want it flexible' and 'we want a personal fit'. Waiting is stupid. We want money dispensed now, we now want to book our air ticket for the next day, just as a hired car and travel insurance. "Kids live a very busy life; who do you think they copy this from?" says an extensive advertising campaign in the Netherlands trying to point out that young people have no time for playing anymore.

\section{Integration of ICT}

Information and Communication Technology is integrating quickly in the Netherlands. The distribution of ICT over the population is rather even and shows no clear boundaries. Particular groups, such as older people, single women, lower educated people and low income people less often have a computer or an Internet connection. However the connectivity rate among all groups is growing so quickly that no insurmountable differences are expected (WRR 2002, p. 68).

\section{Cultural environment}

\section{'Zap'-culture}

Just as electricity in the past, the integration of Information and Communication Technology (ICT), gives rise to profound changes in our culture. Television has promoted a 'zap'-culture, now intensified by ICT. Small chunks of information or entertainment together constitute the mosaic of our cultural experiences, a blip-culture. The penetration of the mobile phone certainly has contributed. The Short Message Service (SMS) has enriched our cultural life with a new form of writing (Table 1). 
Table 1. SMS writings

\begin{tabular}{llllll}
\hline SMS words & Meaning & $\begin{array}{l}\text { SMS } \\
\text { emoticons }\end{array}$ & Meaning & SMS figures & Meaning \\
\hline $\mathrm{Cu}$ & See you & $:-)$ & Just joking & $>^{\wedge} 00^{\wedge}<$ & Cat \\
Id & $\begin{array}{l}\text { Idea } \\
\text {-Id }\end{array}$ & $\begin{array}{l}\text { No } \text { idea } \\
:-<\end{array}$ & $\begin{array}{l}\text { Great laugh } \\
\text { A bit sad }\end{array}$ & $\begin{array}{l}\mid \_ \\
(10 /)\end{array}$ & $\begin{array}{l}\text { Cup of coffee } \\
\text { Angel in } \\
\text { flight }\end{array}$ \\
W8 & Wait & $\begin{array}{l}\text { Very sad } \\
\text { Angry }\end{array}$ & $\left.\left.\left.\left.\left.<^{*}\right\}\right\}\right\}\right\}\right\}<>$ & Fish \\
\hline
\end{tabular}

\section{Virtual communities and cultures}

Information and Communication Technology (ICT) allows the creation of a virtual reality: "a world without limits where the frontier between fact and fiction is fuzzy. The more senses are involved the more real this Virtual Reality is. Here digitalisation is the 'most extreme' form of abstraction. It is learning by experience (but there is a risk involved). It enables money and time efficient creativity." (Weert \& Munro 2003; p. 78). Video and Internet games, with their sub-cultures of players, integrate in our culture. "Internet is transforming the social interaction among different age groups in society in all countries." (Weert \& Munro 2003; p. 77). Granddad and Grandma surf the World Wide Web looking for their cross words puzzle and may be part of a 'community' of cross words fans. "As we have more control, and more isolation and exclusion, we expect to be able to create our own cultures, finding like-minded people in a community, or to establish our own identity and community of interest to the exclusion of others. These communities and cultures can be virtual, but have a very real physical impact." (Kendall et al. 2004).

\section{Globalisation as natural phenomenon}

In the 'Rise of the West' McNeill shows how cultures have influenced one another in all phases of world history. Important economic, social and cultural changes have developed through contact with strangers with new and unfamiliar skills. "A corollary of this proposition is that centers of high skill (i.e. civilizations) tend to upset their neighbours by exposing them to attractive novelties. Less-skilled peoples round about are then impelled to try make these novelties their own ... Yet such efforts provoke a painful ambivalence between the drive to imitate and an equally fervent desire to preserve the customs and institutions that distinguish the would-be borrowers from the corruptions and injustices that also inherent in civilised life." (McNeill 1991; p. xvi) 
McNeill argues that many civilisations which originally where separate entities, have melted together in a new cosmopolitan civilisation, starting 2500 BC in the Middle-East. "This assumes a new dimension when, with the improvement of communication, diverse civilisations begin to impinge one another more and more often and in increasingly urgent ways, since under these circumstances the autonomy and independence of the separate civilisations begins to shrink, an a new cosmopolitan entity - what Wallerstein calls a world system - may start to take over as the key factor in further historical development." (McNeill 1991; p. xxi) Globalisation therefore is a natural phenomenon.

\section{Political environment}

The Lisbon declaration, issued after the extraordinary European Council (2000), showed that the transition to a knowledge intensive society is high on the political agenda. The scale of current economic and social change, the rapid transition to a knowledge-based society and demographic pressures resulting from an ageing population in the industrialised countries are all challenges which demand political attention and a new approach to education and training. This is illustrated by the high priority given to Lifelong Learning in the context of these challenges by meetings of the European Council. These meetings resulted in the communication of the mandate of the Feira European Council. In this communication (Memorandum of Lifelong Learning) Lifelong learning is defined as: "all learning activity undertaken throughout life, with the aim of improving knowledge, skills and competence, within a personal, civic, social and/or employment-related perspective." (Kendall et al. 2004).

\section{A NEW TYPE OF PROFESSIONAL}

\section{Knowledge workers}

Innovation is the driving force in knowledge intensive economies. Therefore the economic focus is on knowledge work: new application of existing knowledge and knowledge creation. Knowledge application and knowledge creation are normal parts of the work of modern professionals. The modern professional is a knowledge worker.

Work of the knowledge worker is organised in non-traditional ways. The aim is to satisfy demand-driven markets and the organisation of work is 
geared towards teamwork, flexibility and quality. Information and Communication Technology (ICT) is omnipresent and empowers the individual to act as expert in many areas. ICT also offers flexibility of time and place in support of teamwork. Work is result oriented and the professionals are accountable on results: team and organisation form a meritocracy.

These new professionals give meaning to their lives through their work. They continually engage in new challenges and learn on the job. They therefore need other skills than in the 'old fashioned' Tayloristic economy. Social-communicative and social-normative skills and competences (soft skills or people skills) are needed to be able to function adequately in teams and cooperate with colleagues: communication skills, empathy, team player skills. Self-direction and autonomy require initiative, pro-activity, flexibility and risk taking of professionals. (WRR 2002, p. 148) Another of these new qualifications is dealing with a professional environment characterized by fast change. For the modern professional life long working is identical with life long learning; the modern professional is a learning professional.

\section{A NEW TYPE OF ORGANISATION}

\section{The Learning Organisation}

To keep up with demands and competition innovative businesses and organisations have to create new operational knowledge in their domain: how to do better and how to offer new products and/or services. In a learning organisation work is organised in non-traditional ways and professionals work in a different way. A shift can be observed from organisational structures suited for efficient, standard, large-scale throughput (Tayloristic, old economy) to structures that facilitate flexible, custom-tailored, small scale, high quality production or servicing (networked, new economy). These new organisational structures aim to satisfy a personal, demand-driven market and are reflected in organisational concepts such as "Just In Time". The new structures are geared towards teamwork, flexibility and quality. Information and Communication Technology (ICT) is omnipresent and empowers the individual to act as expert in many areas. ICT also offers flexibility in time and place in support of teamwork. 


\section{Virtual Learning Organisation}

For flexibility much, but not all, of the work in a learning organisation is distributed in time and place. This requires new ways of work organisation and ICT-integration: the Virtual Learning Organisation. In 'Organisations going virtual' (Metselaar1999) the following typology is presented:

a. Internal virtual organisation;

b. Virtual organisation;

c. Dynamic virtual organisation;

d. Web enterprise or agile organisation.

The last type of ICT-supported organisation (d) is a temporary network of experts working in a specific field or on a specific topic, “...a spatially dispersed and temporarily flexible cultural community, the reproduction of which is dependent upon learning and innovation of its constituents. Knowledge management and the sharing of information among partners are essential elements for an agile organisation". (Metselaar 1999; p. 204)

Knowledge management and information sharing are on the one hand integrated in the primary work processes that are organised in a result oriented way. On the other hand Communities of Practice play a role. The agile organisation therefore is a double-knitted organisation (McDermott 1999). ICT-support is a necessary, but not a sufficient condition for successful knowledge management and information sharing: these two processes have to be organised. Von Krogh, Ichijo and Noanaka give guidelines on how to organise knowledge creation in communities. (Krogh 2000)

\section{A NEW TYPE OF STUDENT}

\section{Homo Zappiens}

A new generation of students is presently knocking at higher education doors: the media generation.(Veen 2002) Wim Veen characterises this media generation as 'Homo Zappiens', in contrast with 'Homo Sapiens'. This media generation has been raised with the remote control of the TV, a computer mouse or a game stick in one hand, and the mobile phone in the other. From early morning till late at night this generation is playing computer games looking for fun and kicks, changing the rules of the game whenever they feel like it. For this generation school is a meeting place, not a learning place. From the teachers' perspective these students are not able to concentrate for very long, being over-active and showing no discipline, nor 
respect (Veen 2002). However, on closer inspection this media generation can be seen to have new competencies:

- Multi-dimensional scanning

Research by Wim Veen reveals that the media generation is able to absorb text, sound, movement, colour and image at the same time and integrate discontinuous information. For example the boy who is zapping from one television channel to the other and still able to reconstruct the plot of a soap running on one of the channels.

- Multi-tasking

The media generation is able to do several tasks at the same time and in a non-sequential way. A media generation girl is doing her home work, at the same time talking on the mobile phone, surfing the World Wide Web and listening to music.

\section{Living is learning}

The media generation is more or less in continuous (digital) communication. New information is applied to meet the challenges of a game or a life of fun and kicks. Parents or education are not necessarily the source of this information: the media generation has its own digital network of 'experts' (communities). Routine is not appreciated; everything has to be new and challenging. Every thing should be an 'experience': for the media generation living is learning and school more a meeting place than a place to learn. They may not always learn what their parents would like them to learn, but learning they do. And what they learn is immediately applied in real or virtual life.

\section{'NEW EDUCATION'}

\section{Higher Education as Virtual learning organisation}

Higher education is facing two challenges:

1. It has to educate the media generation of students,

2. It has to educate starting modern professionals, who are operating in learning organisations.

"Particularly traditional education is not capable of accommodating ever increasing numbers of learners and learning needs at an affordable cost. Large scale introduction of Information and Communication Technology (ICT) to automate traditional education (the textbook, the classroom and the 
teacher) will not bring the solution." (Visser 1999, p. 2) A new educational paradigm is needed in which the higher education learning/working environment for students closely resembles the future working/learning environment of the students. Higher education itself will have to be organised as a virtual learning organisation. "Universities, and other learning institutions, are in need of redefining themselves in much more fundamental ways than by simply continuing their old practices by modern means. The production of knowledge has become a highly networked and increasingly fluid phenomenon. Universities play a role in it, but are no longer the exclusive or even major players. They are in need of continually repositioning themselves. Gibbons refers to the value-added inherent in the creativity to configure knowledge and resources over and over again. These networks of knowledge production are likely to comprise more than just the academic community."(Visser 1999, p. 4) Higher education then is "...a spatially dispersed and temporarily flexible cultural community, the reproduction of which is dependent upon learning and innovation of its constituents. Knowledge management and the sharing of information among partners are essential elements for this organisation". (Metselaar1999, p. 204)

\section{Learning as professional: creative learning}

Students have to learn to develop professional competence. Here an informal, operational definition of competence is used: the ability to solve a 'worth-while' problem with a 'proper' result, following a 'proper' method. This is for example what we expect of a competent medical doctor. Problems have a context and the professional has a role in this context.

Professional learning situations therefore can be characterised by:

- the context,

- the professional role to be performed,

- Problem identification and result specification,

- Working method

- Criteria for the quality of the working process and for the quality of the result (criteria for what is 'proper'),

- Validation, establishing that the working process has been done in the 'proper' way and that the result is the 'proper' result,

- Critical reflection, learning how to do better. 
Table 2. Contrasting views of learning (Duffy 2001)

\begin{tabular}{lll}
\hline & Constructivism view & Acquisition view \\
\hline Learning is: & $\begin{array}{l}\text { Organic } \\
\text { Continual reorganization }\end{array}$ & $\begin{array}{l}\text { Cumulative } \\
\text { Discovery (finding what is } \\
\text { known) }\end{array}$ \\
$\begin{array}{lll}\text { Invention } \\
\text { Knowledge is: }\end{array}$ & $\begin{array}{l}\text { A construction } \\
\text { Mutual respect for views }\end{array}$ & $\begin{array}{l}\text { An acquisition } \\
\text { Transfer of coach's } \\
\text { expertise }\end{array}$ \\
is: & $\begin{array}{l}\text { Ability to converse } \\
\text { Absessment is: }\end{array}$ & Mastery of content \\
\hline
\end{tabular}

Learning as professional implies a paradigm change from 'acquisition view' to 'constructivism view' as presented by Duffy (Table 2). In the new learning/working situation the student is a starting modern professional, a knowledge worker who combines learning, working and knowledge creation. (Weert 2002) Let us denote this type of learning/working situation as Situation based learning situation. In this learning situation Validation is the essential element to ensure quality and Critical reflection the essential element to ensure learning.

\section{EXAMPLE: VIRTUAL ENVIRONMENTAL CONSULTANCY AGENCY}

A Higher Education example of a Virtual learning organisation in which students learn as creative modern professionals is the "Virtual Environmental Consultancy Agency" (VECA), described in (Ivens 2002). This student consultancy agency (see Figure 1.) was first started in 2000 by the Open University of the Netherlands in co-operation with Maastricht University. It was further developed in 2001 and is currently operating in the context of the Dutch Digital University. It is based on earlier experiences within the Open University of the Netherlands with the concept of 'Virtual Company'. The VECA is mediated via a computer network. It combines the flexibility of distance learning with integration of learning and working. 


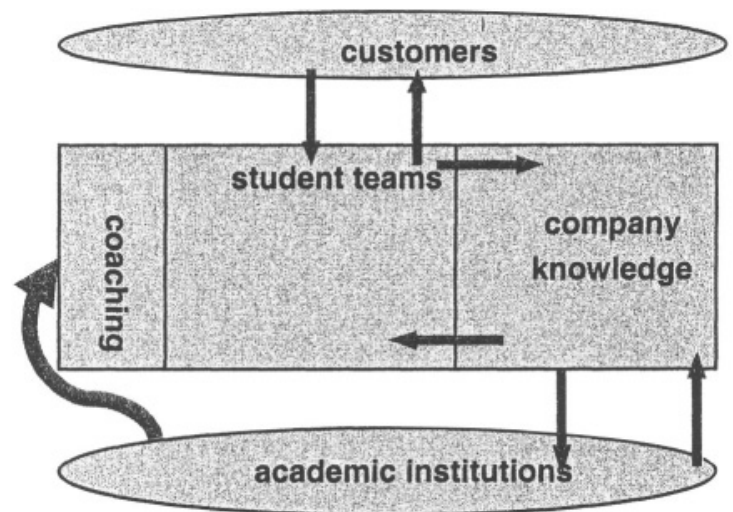

Figure 1. Virtual Environmental Consultancy Agency (Ivens 2002)

Within the VECA, all processes are dominated by the concept of competence learning: learn how to complete professional tasks by integrating complexes of knowledge, skills and attitudes. This implies that before the start-up an exhaustive inventory has to be made of the competencies required. The resulting competence map is pivotal because it acts as a frame of reference for all processes involved: it limits the range of products and services rendered, and defines what can be learned by the students.

In running a VECA one can distinguish three main phases: the preparatory phase, the actual working period en the final assessment.

\section{Preparation}

During the preparation phase potential orders are acquired from external clients. These orders are mapped into a competence map, first of all to decide whether they will be accepted or not.

Furthermore, students have to be recruited. Competence counsellors, who are members of the educational staff, diagnose new students against the competence map. Identified gaps in competence constitute the student's career plan. The career plan is subsequently used as the starting point for assigning sensible tasks to the students. 


\section{The working period}

The work starts with a plenary face-to-face introductory meeting. Thereafter project teams start carrying out their work. An extensive system is established that monitors and assesses students' (in) competencies. It includes traditional teacher controlled evaluation (co-assessment) procedures as well as methods for self- and peer-assessment by the students themselves. The latter are used to assess the individual's informal knowledge and functioning. The working period is concluded with a final face-to-face meeting where results are presented to the external clients and all members (students and teachers) of the VECA.

\section{Final assessment}

All documents produced in the course of a student's career, for example results of assessments and results produced for customers, are collected in a personal portfolio which forms the basis of establishing and formalising performance levels. By asking the customers to assess the merit of the final result an external assessment of the student's work is made. This is also incorporated into the portfolio. Collectively these assessments contain a reflection on the effectiveness and quality of the entire learning environment, including the teaching. Based on the portfolio the examiner establishes a final mark for each individual student.

Table 3. Prototyping approach to 'New Education'

\begin{tabular}{lllll}
\hline $\begin{array}{l}\text { Prototyping } \\
\text { situation }\end{array}$ & $\begin{array}{l}\text { Student } \\
\text { responsible for }\end{array}$ & Way of working & $\begin{array}{l}\text { Student role } \\
\text { (Duffy 2001) }\end{array}$ & Teacher role \\
\hline $\begin{array}{l}\text { Assignment } \\
\text { based } \\
\text { traditional) }\end{array}$ & $\begin{array}{l}\text { Execution } \\
\text { Validation }\end{array}$ & Prescribed & $\begin{array}{l}\text { Reproductive } \\
\text { (Know What) }\end{array}$ & $\begin{array}{l}\text { Presenter } \\
\text { Assessor }\end{array}$ \\
& $\begin{array}{l}\text { Planning } \\
\text { execution }\end{array}$ & Adaptive & $\begin{array}{l}\text { Executive } \\
\text { (Know How) }\end{array}$ & $\begin{array}{l}\text { Task designer } \\
\text { Coach } \\
\text { Validation }\end{array}$ \\
& $\begin{array}{l}\text { Reflection } \\
\text { Choice of } \\
\text { Problem based }\end{array}$ & Problem & Tactical & Problem \\
& $\begin{array}{l}\text { (Know Why) } \\
\text { designer }\end{array}$ & Coach \\
& $\begin{array}{l}\text { Planning } \\
\text { Execution } \\
\text { Validation }\end{array}$ & dependent & & (Assessor) \\
& Reflection & & &
\end{tabular}




\begin{tabular}{lllll}
\hline $\begin{array}{l}\text { Prototyping } \\
\text { situation }\end{array}$ & $\begin{array}{l}\text { Student } \\
\text { responsible for }\end{array}$ & Way of working & $\begin{array}{l}\text { Student role } \\
\text { (Duffy 2001) }\end{array}$ & Teacher role \\
\hline Situation based & $\begin{array}{l}\text { Choice of } \\
\text { problem }\end{array}$ & $\begin{array}{l}\text { Situation } \\
\text { dependent }\end{array}$ & $\begin{array}{l}\text { Strategic } \\
\text { (Care Why) }\end{array}$ & $\begin{array}{l}\text { Quality process } \\
\text { designer } \\
\text { Consultant } \\
\text { Coach }\end{array}$ \\
& $\begin{array}{l}\text { Choice of } \\
\text { method }\end{array}$ & & (Assessor) \\
& Planning & & \\
& Execution & & & \\
& Validation & & & \\
& Reflection & & & \\
& & & & \\
& & & & \\
& & & & \\
\end{tabular}

\section{Discussion}

The VECA learning environment in an example of a Situation based learning environment that is fairly authentic. Student influence on the process is however limited. Validation as a means to let students control quality is integrated in the process. There is intake assessment, but only with respect to student competencies and their relation to the Competence Map; students are not involved in the project selection. The students create a Personal Development Plan themselves, but the teaching staff decide on the project, on the role of the student and on competencies to be developed. Authenticity here could be better. There is on-going validation of and critical reflection on process and intermediate results. An external expert is involved in the final assessment, mainly to assess the final result and its presentation, but also to assess customer management.

The virtual learning organisation VECA could also easily be used in a lifelong learning context involving professionals who want to update existing competencies or acquire new ones.

\section{A PROTOTYPING APPROACH TO 'NEW EDUCATION'}

Redefinition of Higher Education is a complex process of change. It is virtually impossible to create Situation based learning environments in which students learn/work as starting modern professionals, from scratch.

A prototyping approach as presented in Table 3 (Weert 2001) may offer an effective learning environment for both higher education institutions and students. The prototypes allow students to develop a career towards starting modern professional, moving from a reproductive to a strategic role. At the same time Higher Education teachers can develop a career from presenter of 
knowledge (acquisition view) to consultant/coach. And the Higher Education organisation can develop a career towards a virtual learning organisation.

\section{REFERENCES}

Beek, K. van (1998) De ondernemende samenleving. Een verkenning van maatschappelijke verandering en implicaties voor beleid, Wetenschappelijke Raad voor het Regeringsbeleid, Voorstudies en achtergronden V104, Sdu Uitgevers, Den Haag.

Duffy, Th. M. \& Ch. Orrill (2001) Constructivism, in Kovalchic A. \& K. Dawson (Eds.), Educational Technology, An Encyclopedia. Santa Barbara, CA: ABC-CLIO.

Ivens, W. P.M.F. (2002) New ways of academic education: chances for sustainability, in: "COPERNICUS in Lüneburg; Higher education in the Context of Sustainable Development and Globalization" (Eds., M.C.E. van Dam-Mieras, G. Michelsen H.P. Winkelmann),p.111-118.

Kendall, M. \& B. Samways, T. van Weert (Ed.), J. Wibe (2004) IFIP TC3 Position Paper on Lifelong Learning. In: (Weert, Tom J. van \& Mike Kendall, 2004).

Krogh, G. von, Ichijo, K., Noanaka, I. (2000) Enabling Knowledge Creation, Oxford University Press, Oxford.

McDermott, R. (1999) Learning across teams, How to build communities of practice in team organizations, Knowledge Management Review, 8 (May/June 1999).

Mc.Neill, W. H. (1991) The rise of the West, A history of the human community, University of Chicago Press, Chicago.

Metselaar, C. \& van R. van Dael (1999) Organisations going virtual, AI \& Soc (1999) 13, p.p. 200-209.

Sociaal-Economische Raad (1999) SER Adviezen, nr. 1999/04 Hoger Onderwijs en Onderzoek Plan 2000, SER, Den Haag, 1999.

Tapscott, D. (1996) Digital Economy, Promise and peril in the age ofnetworked intelligence, McGraw-Hill.

Veen, W. (2002) Students of the media generation, Coping with homo zappiens, Voordracht op de SURF Onderwijsdagen 2002, SURF, Utrecht.

(http://www.surf.nl/onderwijsdagen2002/video/veen/index.htm) (accessed May 2003)

Visser, J. (1999) Changing learning environments: The real and not so real of reality and virtuality, Learning without frontiers (www.unesco.org/education/lwf) (accessed December 2003). 
Weert, Tom J. van (2001) Co-operative ICT-supported learning, A practical approach to design. In: Keil-Slawik, Reinhard \& Johannes Magenheim (Hrsg.), Informatikunterricht und Medienbildung INFOS 2001, GI-Edition - Lecture Notes in Informatics (LNI) Proceedings Series of the German Informatics Society (GI), Springer Verlag, 2001, p.p. 47-61.

Weert, T. J. van (2002) Lifelong learning in Virtual Learning Organisations, Designing virtual learning environments, in: Passey, D. and M. Kendall (Eds.) TelE-LEARNING, The Challenge for the Third Millennium, Kluwer Academic Publishers, Boston/Dordrecht/London, p. 135-142.

Weert, T. van \& Munro, B. (Eds.) (2003) Informatics and the Digital Society, Social, ethical and cognitive issues, Proceedings of SECIII, Kluwer Academic Publishers, Boston/Dordrecht/London.

Weert, Tom J. van \& Mike Kendall (Eds.) (2004) Lifelong Learning in the Digital Age, Sustainable learning for all in a changing world. Kluwer Academic Publishers, Boston.

Wetenschappelijke Raad voor het Regeringsbeleid (WRR) (2002) Van oude en nieuwe kennis, De gevolgen van ICT voor het kennisbeleid, Sdu Uitgevers, Den Haag. Reports to the government 61, Of old and new knowledge, the consequences of ict for knowledge policy. (http://www.wrr.nl/en/frameset.htm) (accessed March 2003). 